\title{
Investigation of Antibacterial Activity of Footwear Leather Obtained from Different Tanning
}

\author{
Levent Inanc ${ }^{1 *}$, Nazime Mercan Dogan ${ }^{2}$ \\ ${ }^{1}$ Denizli Vocational School of Technical Sciences, Pamukkale University, Kınıklı, Denizli 20013, Turkey \\ ${ }^{2}$ Pamukkale University, Faculty of Science and Arts, Department of Biology, Denizli, Turkey
}

Corresponding Author: Levent Inanc linanc@pau.edu.tr

\begin{abstract}
In present study, antibacterial properties of leathers prepared by different tanning processes such as chromium, vegetable (mimosa and quebracho) and wet-white (modified glutaraldehyde) processes were analyzed by qualitative and quantitative tests. Staphylococcus aureus ATCC 33862 and Bacillus cereus NRRL-B-3711 as a representative of Gram-positive, Escherichia coli ATCC 25922 as a representative of Gram-negative were used in our study. The best inhibition effect was achieved against S. aureus by disc diffusion method. According to the bacterial reduction performance of leathers, the antibacterial property of vegetable tanned samples was higher than that of chrome and wet-white tanned samples against E. coli. The surface morphology of the leathers was also examined by scanning electron microscopy (SEM). In SEM analysis, the pores of chrome tanned leather were found to be larger than those of vegetable and wet white tanned leather, and these results were verified by the imagej program. We considered that the antibacterial properties of leathers can be improved by various plant extracts.
\end{abstract}

\author{
ARTICLE HISTORY \\ Received: 20.09.2019 \\ Accepted: 11.08.2020
}

\section{KEYWORDS}

Antibacterial activity, Leather, Chromium, Vegetable,

Wet-white

\section{INTRODUCTION}

The production of the leather removes unwanted substances from the raw material, makes it durable by tanning, and gains the desired properties in the product with post-tanning and finishing processes. The exact definition of the tanning is the conversion of an organic substance that can be degraded by bacteria into durable [1]. The types of tanning are mainly divided into three classes: (a) mineral, (b) vegetable, and (c) aldehyde [2].

Finished products of leather such as bags, clothes and shoes have been mostly being the essential requirements in people's lives. Especially in footwear, being in contact with foot very long periods of time can be promote proliferation of microorganisms such as molds, yeasts and bacteria, because of inadequate ventilation, suitable humidity and temperature conditions for microbial growth $[3,4]$. These developing microorganisms have a great problem in terms of the chemical structure of the leather [5]. Loss of elasticity, spots on surface, and unpleasant odor occurs in the leather because of microorganisms' enzymatic activity. Moreover, many microorganisms, such as Corynebacterium spp., Clostridium spp., Staphylococcus spp., Pseudomonas spp, Enterobacter spp., E. coli and Candida albicans can be pathogenic to humans $[6,7,8]$. Diabetics are more sensitive to bacteria and bacteria can stimulate the risk of foot ulceration [9]. For this reason, the prevention of the microorganism's growth on the leather products is important [10]. Many researchers have been coated of leather with different nanoparticles for inhibition of microorganisms' growth. For example, these nanoparticles including zinc oxide [11,12], gold [13], silver [4,8,14] have been studied in numerous researches. Silver nanoparticles as well as other nanoparticles might create positive and negative effects. For instance, some nanoparticles have a potential of entrance in the blood-brain barrier preserved the brain from hazardous chemicals in the blood [15]. Also, the antimicrobial properties of leathers coated with plant extracts was analysed by some researchers $[5,13,16,17]$.

To cite this article: İnanç L, Mercan Doğan N. 2020. Investigation of Antibacterial Activity of Footwear Leather Obtained from Different Tanning. Tekstil ve Konfeksiyon, 30(3), 184-189. 
The present study was aimed to investigate the antibacterial activity of leathers obtained from different tanning process. The surface morphologies of leather samples were also analyzed by SEM.

\section{MATERIAL AND METHODS}

\subsection{Leather Materials}

The nine pieces of dry salted hides which compose the raw material of the study were belonged to the domestic male bovine of the angus race. Hides were divided into two from the neck towards the tail through the belly line and eighteen sides of the hides were obtained. These sides were tanned with chrome, vegetable and wet-white conventional processed accordingly for upper leather. The conventional finishing chemicals were used in the leather finishing processes.

\subsection{Test Bacteria and Growth Medium}

Staphylococcus aureus ATCC 33862, Bacillus cereus NRRL-B-3711 and Escherichia coli ATCC 25922 were used. Bacteria were obtained from Bacteriology Laboratory of Biology Department, Pamukkale University. Tryptic Soy Broth and Tryptic Soy Agar (Merck) was used as growth media in study. The culture suspensions were prepared, according to the turbidity of a $0.5 \mathrm{McFarland}$ standard.

\subsection{Antibacterial Activity}

The inhibitory effect of leathers was detected on solid medium. Leathers are degraded at high temperature. First, the leather materials were cut into $6 \mathrm{~mm}$ diameter discs and the surface sterilization of the leathers was done with ethyl alcohol $(70 \% \mathrm{w} / \mathrm{v})$ for 4 hours in sterile conditions. After then, they sterilized in autoclave at $90^{\circ} \mathrm{C}$ for 5 minutes. Sterile leather discs were placed on solid medium with bacteria. After incubation $24 \mathrm{~h}$, the inhibition zone diameter around the leather discs was measured in $\mathrm{mm}$. All manipulations were duplicated in our study [18].

Antibacterial activity of the leather materials was evaluated by using gram-negative $E$. coli and gram-positive $S$. aureus and $B$. subtilis. The colony counting method was used and the antibacterial activity was called as the percentage of cell reduction [10]. For this purpose, bacteria were grown to get the logarithmic phase in Tryptic soy broth (TSB) at $37^{\circ} \mathrm{C}$ and diluted in medium to obtain a concentration of $1 \times 10^{8}$ colony-forming units per milliliter; $\mathrm{CFU} / \mathrm{ml}$. The cell suspension was seeded into glass tubes in the presence of leathers (6 mm diameter discs) and incubated at $37^{\circ} \mathrm{C}$ for $24 \mathrm{~h}$. For estimating the number of viable bacteria remaining in the medium, the serial dilutions were prepared and $100 \mu \mathrm{l}$ of dilution were spread on solid agar medium. After incubation for $24 \mathrm{~h}$ at $37{ }^{\circ} \mathrm{C}$, the colonies on solid medium were counted and the colony-forming unit (CFU) values were determined. The bacterial suspensions without leather discs were tested under the same conditions as the negative control. The reduction rate $(\%)$ was calculated according to the following formula:

$\%$ Reduction $=[(\mathrm{A}-\mathrm{B}) / \mathrm{A}] \times 100$

$\mathrm{A}$ : the colony counting in the tube without leathers
$\mathrm{B}$ : the colony counting in the tube with leathers

\subsection{Scanning Electron Microscope (SEM) Analysis of Leathers}

SEM images were performed on gold-coated samples using a Carl Zeiss Supra 40 VP Field Emission Scanning Electron Microscope (FE-SEM) at the Pamukkale University (Denizli, Turkey). Also, the surface of leather samples was analyzed based on the photographs using software, Image $1.49 \mathrm{~b}$.

\section{RESULTS AND DISCUSSION}

\subsection{Antibacterial Properties of Leathers}

S. aureus, E. coli and B. cereus are common human pathogens and they cause a wide range of clinical infections such as skin and soft tissue, bacteremia, infective endocarditis and devicerelated infections [19-25]. The bacterial infections of the skin are among the most common infections in the community. Being in contact with the foot for a long time in poorly ventilated environment, humidity and temperature conditions cause the proliferation of pathogens in leather shoes. The population of foot bacterial flora decreases and the risk of skin colonization by human pathogens increase $[3,4,26]$. That's why, the use of leathers with antimicrobial properties in the manufacture of shoes, garment leather, etc. is important for human health and hygiene [27].

In our study, the antibacterial properties of leathers treated with the chromium, vegetable and wet-white was analyzed by qualitative and quantitative tests against $S$. aureus, E. coli and $B$. cereus. Table 1 has shown the results of the inhibition zones $(\mathrm{mm})$ of leather discs. In general, the leather samples showed the different inhibition zones. It was found that Bacillus cereus NRRL-B-3711 and Escherichia coli ATCC 25922 were resistant than S. aureus ATCC 33862. On the other hands, the leather samples were more effective against $S$. aureus. Furthermore, there were bacterial colonies under the leather discs for E. coli and B. cereus while the inhibition zone wasn't seen around and beneath some leather samples for $S$. aureus. The antibacterial properties of the leathers tanned with vegetable (7.4-15.4 mm) was found to be more effective than that of wet-white $(4.75-10 \mathrm{~mm})$ and chromium (5.75-10.1 mm). In our opinion, the using different bacterial species or different tanned leathers caused the different inhibition zones.

The antimicrobial and physical properties of leathers coated with plant extracts was reported by some researchers. According to the findings of López et al. (2015), the leathers with Aloe vera extract had a powerful antibacterial effect against $S$. aureus, B. subtilis, E. coli and $K$. pneumonia [3]. Raji et al. (2019) verified that the combinations of tannins from Cassia alata plant with chromium were improved the properties of leathers such as tensile and tear strength, shrinkage temperature and thickness [16]. In other study, the inhibition effect of raw skin and chrome-tanned leather samples treated with the acetone and chloroform extracts of Pseudevernia furfuracea lichens were detected against some bacteria, fungus and yeast species [17]. 
Table 1. The inhibition zone diameter of leathers $(\mathrm{mm})$

\begin{tabular}{|c|c|c|c|c|c|c|c|}
\hline $\begin{array}{c}\text { DYED } \\
\text { CRUST } \\
\text { LEATHER } \\
\end{array}$ & $\begin{array}{l}\text { E. coli } \\
\text { ATCC } \\
25922 \\
\end{array}$ & $\begin{array}{c}\text { S. aureus ATCC } \\
33862\end{array}$ & $\begin{array}{c}\text { B. cereus } \\
\text { NRRL-B- } \\
3711 \\
\end{array}$ & $\begin{array}{l}\text { FINISHED } \\
\text { LEATHER }\end{array}$ & $\begin{array}{l}\text { E. coli } \\
\text { ATCC } \\
25922 \\
\end{array}$ & $\begin{array}{c}\text { S. aureus } \\
\text { ATCC } \\
\mathbf{3 3 8 6 2} \\
\end{array}$ & $\begin{array}{c}\text { B. cereus } \\
\text { NRRL-B- } \\
3711 \\
\end{array}$ \\
\hline CCL-1 & $\mathrm{b}$ & $\mathrm{a}$ & $6.0 \pm 0$ & CFL-1 & $\mathrm{b}$ & $\mathrm{a}$ & $5.75 \pm 0.75$ \\
\hline CCL-2 & $\mathrm{b}$ & $\mathrm{a}$ & $\mathrm{b}$ & CFL-2 & $\mathrm{b}$ & $\mathrm{a}$ & b \\
\hline CCL-3 & $\mathrm{b}$ & $10.1 \pm 0.1$ & $\mathrm{~b}$ & CFL-3 & $\mathrm{b}$ & $9.15 \pm 0.15$ & $\mathrm{~b}$ \\
\hline VCL-4 & $\mathrm{b}$ & $11.3 \pm 0.7$ & $\mathrm{~b}$ & VFL-4 & $\mathrm{b}$ & $15.4 \pm 1.8$ & $\mathrm{~b}$ \\
\hline VCL-5 & $9 \mathrm{~mm} \pm 0$ & $\mathrm{a}$ & $\mathrm{b}$ & VFL-5 & $7.4 \pm 0.2$ & $8.5 \pm 0.5$ & $\mathrm{~b}$ \\
\hline VCL-6 & $\mathrm{b}$ & $13 \pm 1$ & $\mathrm{~b}$ & VFL-6 & $\mathrm{b}$ & $12 \pm 2$ & $\mathrm{~b}$ \\
\hline WCL-7 & $\mathrm{b}$ & $\mathrm{a}$ & $\mathrm{b}$ & WFL-7 & $\mathrm{b}$ & $\mathrm{a}$ & $\mathrm{b}$ \\
\hline WCL-8 & $\mathrm{b}$ & $10 \pm 0$ & $\mathrm{~b}$ & WFL- 8 & $\mathrm{~b}$ & $7.5 \pm 0.5$ & $\mathrm{~b}$ \\
\hline WCL-9 & $\mathrm{b}$ & $4.75 \pm 0.25$ & $b$ & WFL-9 & $5.5 \pm 0.5$ & $\mathrm{a}$ & $b$ \\
\hline
\end{tabular}

a: No inhibition zone and no cell growth beneath the leather discs; b: No inhibition zone and cell growth beneath the leather discs;

CCL: chromium crust leather, CFL: Chromium finished leather, VCL: Vegetable crust leather VFL: Vegetable finished leather, WCL: Wet white crust leather, WFL: Wet white finished leather

Velmurugan et al. prepared the green synthesis of silver nanoparticles (AgNPs) by Erigeron annuus flower extract as reducing and capping agent and determined the antibacterial properties of cotton fabrics and tanned leather samples against Brevibacterium linens and Staphylococcus epidermidis. In their study, the maximum inhibition zone was obtained from the cotton fabrics embedded with blend of flower extract and AgNPs against B. linens [13]. In a similar study on the antimicrobial performance of leather materials, the quantitative test results showed that leather samples coated with $\mathrm{nAg}$ reached the highest antibacterial activity against $E$. coli with $99.25 \%$ and against $S$. aureus with $99.91 \%$ [4]. In our study, the antibacterial performance of the vegetable-tanned leathers was found to be higher than that of wet-white and chromium-tanned leathers (Table 2 ). The chromium finished leather (CFL-1) inhibited only the growth of $B$. cereus $(47.08 \%)$ among all leather samples. The maximum bacterial reduction rate was reached with the vegetable-tanned leather samples $(92.33 \%$ and $84.66 \%$ for E. coli and $51.52 \%, 81.54 \%$ and $51.40 \%$ for $S$. aureus). In detailed, the vegetable-tanned crust leather (VCL-5) and finished leather (VFL-5) demonstrated good percentage reduction against $E$. coli of $84.66 \%$ and $92.33 \%$, respectively. While the percentage reduction rate of all leathers was less for S. aureus, only VCL-5 reached good reduction rate $(81.54 \%)$. The applicability of wet blue leathers obtained by using Origanum sp and Schinus molle essential oils as bactericide against $S$. aureus, B. cereus and $E$. coli was investigated and the antibacterial activity of oregano essential oil for $B$. cereus and $S$. aureus was reported by authors [28]. We thought that this situation was due to the specificity of plant extract-microorganisms.

\subsection{Sample Imaging by Scanning Electron Microscopy (SEM)}

Scanning electron micrographs showing the grain surface of the leathers tanned with chromium (a-d), vegetable (e-h) and wet-white (i-1) at a magnification of 150 and 500 are shown in Figure 1, respectively. The grain surface and the hair pores of leather samples were seem to be visible. It was found that chromium tanned leathers have a small number of large pores as shown in Fig. 1a-d, while vegetable and wet-white tanned leathers have many small pores (Figure 1e-h and Figure 1i-l). The higher magnification $(\times 500)$ of scanning electron micrographs confirmed the lower magnification observation and where the hair follicles look clean without any foreign materials in all cases, as shown in Figure $1 \mathrm{~b}, \mathrm{~d}, \mathrm{f}, \mathrm{h}, \mathrm{j}$ and $\mathrm{l}$. Also it was examined SEM graphs of all finished leather samples and it was observed that the dimensions of pores were reduced with the finishing of the leather. These graphs were good findings of the appearance of dyed crust and finished leathers according to different types of tanning. The large pores in chromium tanned leathers may be due to the fact that the properties of chrome affinity are less than that of vegetable tanning agents (mimosa and quebracho) and modified glutaraldehyde. Moreover, large pores provide a healthy product because it increases the air permeability of the leather. Contrary of chromium tanned leather; the vegetable tanned leathers had small and numerous pores. Herewith, an excess of pores may also be an advantage for a healthy leather product. In present study, the electron micrographs of all leather samples were analyzed by ImageJ software and the total area of surface and pores were measured. The results on Image J of leather samples are illustrated in Table 4. From these data, the efficiency of tanning agent was, in increasing order: chromium $>$ vegetable $>$ wet-white. The area of pore was to be $18.1 \%$ (for chromium tanned leather), $7.7 \%$ (for vegetable tanned leather) and $7.6 \%$ (for wet-white tanned leather). These results were in good agreement with the SEM images as given in Figure 1. 


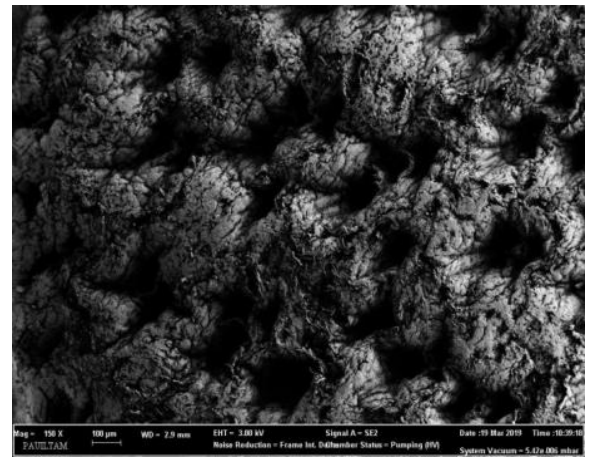

a

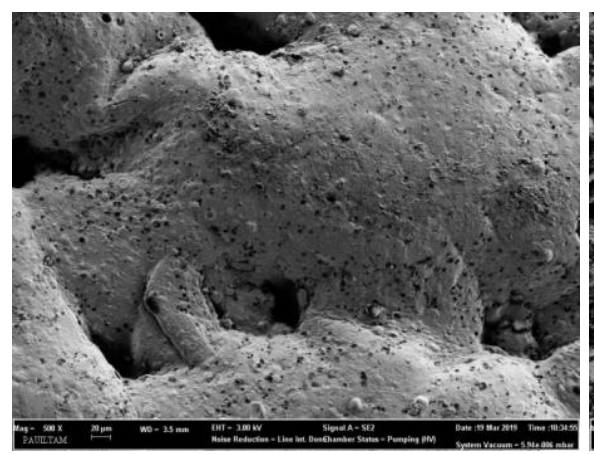

d

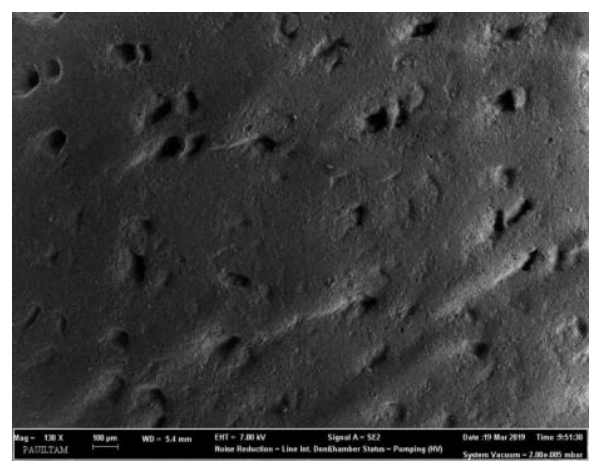

g

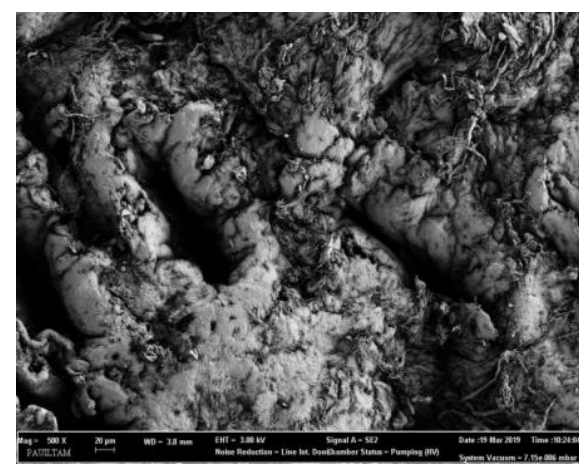

j

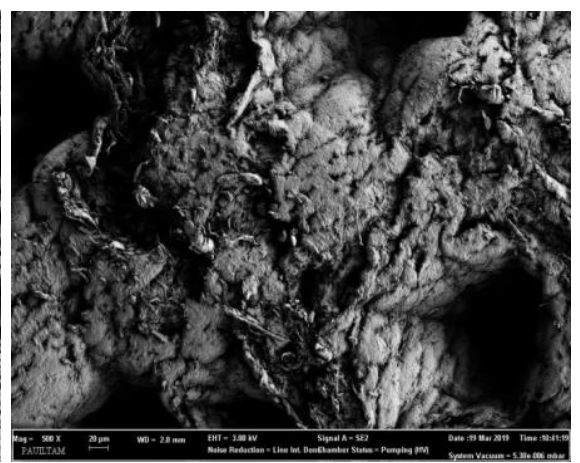

b

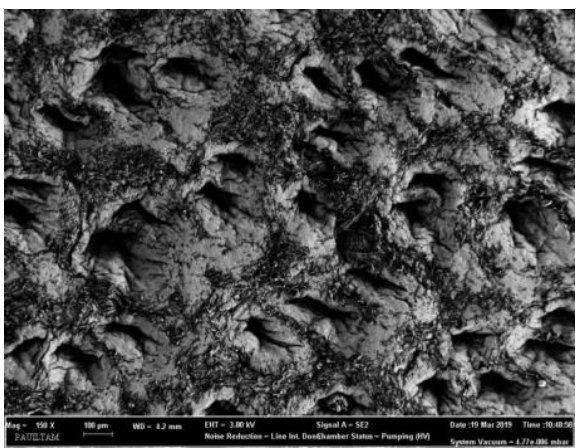

$\mathbf{e}$

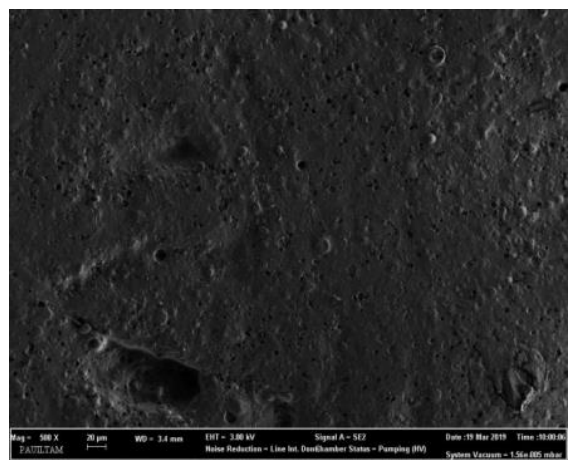

h

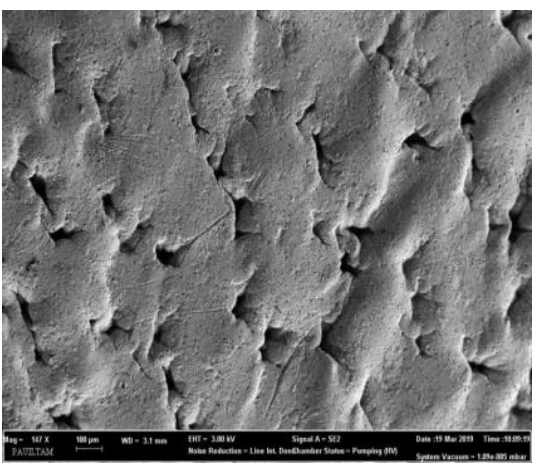

k

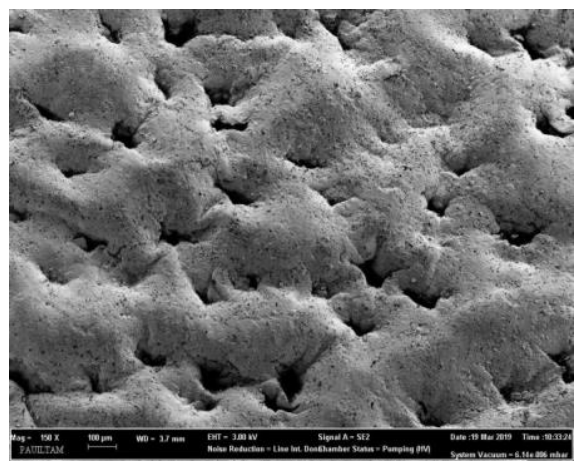

C

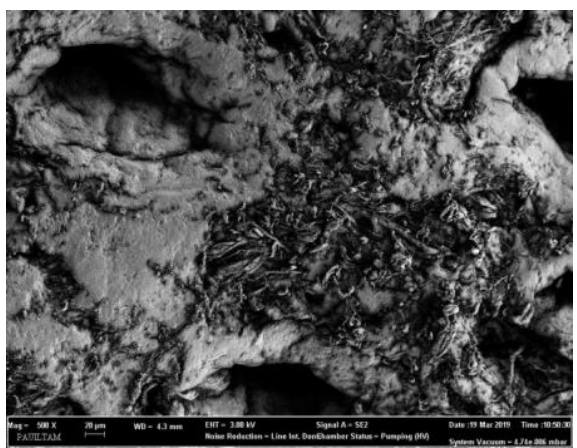

f

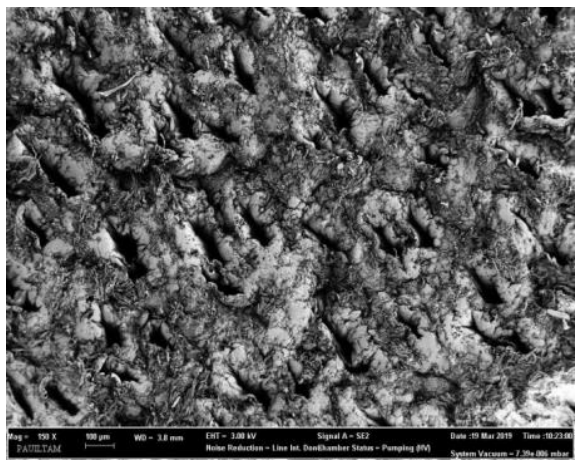

i

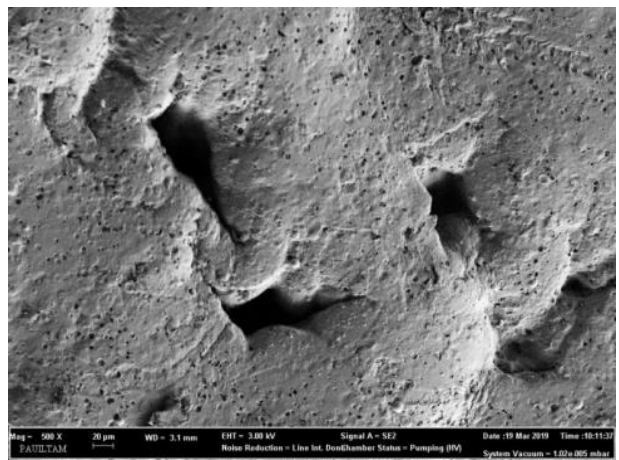

I

Figure 1. a-b) SEM images for the leathers chromium tanned dyed crust (sample1), c-d) SEM images for the leathers chromium tanned finished (sample10), e-f) SEM images for the leathers vegetable tanned dyed crust (sample4), g-h) SEM images for the leathers vegetable tanned finished (sample13), i-j) SEM images for the leathers wet-white tanned dyed crust (sample7), k-l) SEM images for the leathers wet-white tanned finished (sample16) 
Table 2. Bacterial reduction rate $(\%)$

\begin{tabular}{|c|c|c|c|}
\hline Leather samples & E. coli ATCC 25922 & B. cereus NRRL-B-3711 & S. aureus ATCC 33862 \\
\hline CCL-1 & - & - & - \\
\hline CCL-2 & - & - & - \\
\hline CCL-3 & - & - & $25 \pm 2,0$ \\
\hline CFL-1 & - & $47.08 \pm 0.08$ & - \\
\hline CFL-2 & - & - & - \\
\hline CFL-3 & - & - & $7.69 \pm 0.00$ \\
\hline VCL-4 & - & - & $51.52 \pm 0.5$ \\
\hline VCL-5 & $84.66 \pm 0.00$ & - & $81.54 \pm 0.5$ \\
\hline VCL-6 & - & - & $9.98 \pm 0.00$ \\
\hline VFL-4 & - & - & $43.38 \pm 1.03$ \\
\hline VFL-5 & $92.33 \pm 0.91$ & - & $30.46 \pm 2.00$ \\
\hline VFL-6 & - & - & $51.40 \pm 0.00$ \\
\hline WCL-7 & - & - & $36.15 \pm 5.98$ \\
\hline WCL-8 & - & - & $9.23 \pm 0.00$ \\
\hline WCL-9 & - & - & $32.65 \pm 2.5$ \\
\hline WFL-7 & - & - & $20 \pm 1.00$ \\
\hline WFL-8 & - & - & $12.31 \pm 0.00$ \\
\hline WFL-9 & $15.14 \pm 0.04$ & - & $21.23 \pm 1.01$ \\
\hline
\end{tabular}

-: No reduction

Table 3. The results of imagej processing software

\begin{tabular}{lllllll}
\hline & \multicolumn{2}{l}{ Chromium } & \multicolumn{2}{c}{ Vegetable } & \multicolumn{2}{c}{ Wet-White } \\
\cline { 2 - 7 } & $\begin{array}{l}\text { Dyed Crust } \\
\text { Leather }\end{array}$ & Finished Leather & $\begin{array}{l}\text { Dyed Crust } \\
\text { Leather }\end{array}$ & $\begin{array}{l}\text { Finished } \\
\text { Leather }\end{array}$ & $\begin{array}{l}\text { Dyed Crust } \\
\text { Leather }\end{array}$ & $\begin{array}{l}\text { Finished } \\
\text { Leather }\end{array}$ \\
\cline { 2 - 7 } Total pore area $\left(\mu \mathrm{m}^{2}\right)$ & 521.725 .365 & 173.502 .000 & 222.410 .338 & 112.235 .434 & 226.081 .533 & 120.627 .690 \\
Surface area $\left(\mu \mathrm{m}^{2}\right)$ & 2.364 .859 .518 & 2.710 .890 .000 & 2.650 .095 .788 & 3.782 .699 .168 & 2.734 .773 .891 & 2.811 .634 .414 \\
Total leather area $\left(\mu \mathrm{m}^{2}\right)$ & 2.886 .584 .883 & 2.884 .392 .000 & 2.872 .506 .126 & 3.894 .934 .602 & 2.960 .855 .424 & 2.932 .262 .104 \\
Total pore Area $(\%)$ & 18.1 & 6.0 & 7.7 & 2.9 & 7.6 & 4.1 \\
\hline
\end{tabular}

\section{CONCLUSION}

In summary, we investigated the antibacterial properties of leathers prepared by different tanning methods such as chromium, vegetable (mimosa and quebracho) and wetwhite (modified glutaraldehyde). In general, leather samples showed a more specific effect on $S$. aureus compared to $E$. coli and B. cereus. Nevertheless, the reduction rates of the vegetable-tanned crust and finished leathers (VCL-5 and VFL-5) were significant for E. coli. Especially, the leathers tanned vegetable showed better antibacterial activity than leathers tanned chromium and wet-white. The leathers tanned with chromium have got unique properties. The antibacterial activity of leather tanned with vegetable is better than the leather tanned with chromium. The antibacterial properties of plant extracts are well known. In other words, the mimosa and quebracho may be providing a good antibacterial property to leather. Also, the surface morphology and pores of leather samples were sighted by SEM. The total pore, surface and leather area were confirmed by imagej program. According to our findings, the interaction of leathers-bacteria should also investigate in detailed. Besides, we considered that the antibacterial properties of leathers can be developed with different plants extract.

\section{ACKNOWLEDGEMENT}

The authors thank to Dr. Semih Tan (Pamukkale University, Faculty of Medicine, Department of Histology and Embriology) for providing software, Image J $1.49 \mathrm{~b}$. 


\section{REFERENCES}

1. Covington T. 2009. Tanning chemistry. The Science of Leather. The University of Northampton, Northampton, UK: RSC publishing.

2. Sreeram KJ, T Ramasami. 2003. Sustaining tanning process through conservation, recovery and better utilization of chromium. Resources, Conservation and Recycling 38(3), 185-212.

3. Maestre-López IM, Payà-Nohales FJ, Cuesta-Garrote N, Arán-Ais F, Martínez-Sánchez MA, Orgiles-Barceló C, Bertazzo M. 2015. Antimicrobial effect of coated leather based on silver nanoparticles and nanocomposites: synthesis, characterisation and microbiological evaluation. Journal of Biotechnology and Biomaterials 5(1), 1-10.

4. Lkhagvajav N, Koizhaiganova M, Yasa I, Celik E, Sari O. 2015 Characterization and antimicrobial performance of nano silver coatings on leather materials. Brazilian Journal of Microbiology 46(1), 41-48.

5. Chirila C, Berechet MD, Deselnicu V. 2016. Thyme essential oil as natural leather preservative against fungi. ICAMS

6. Gutarowska B. 2013. Niszczenie materiałów technicznych przez drobnoustroje. LAB Laboratoria, Badania 18(2), 10-14. (in Polish)

7. Vouga M, Greub G. 2015. Emerging bacterial pathogens: the past and beyond. Clinical Microbiology and Infection 22, 12-21.

8. Bielak E, Sygula-Cholewinska J. 2017. Antimicrobial effect of lining leather fatliquored with the addition of essential oils. Biotechnology and Food Science 81(2), 149-157.

9. Jeffcoate WJ, Harding KG. 2003. Diabetic foot ulcers. The Lance $361,1545-1551$.

10. Luo Q, Gao H, Peng L, Liu G, Zhang Z. 2016. Synthesis of PEGylated chitosan copolymers as efficiently antimicrobial coatings for leather. Journal of Applied Polymer Science 133(22), 1-7.

11. Gunalan S, Sivaraj R, Rajendran V. 2012. Green synthesized ZnO nanoparticles against bacterial and fungal pathogens. Progress in Natural Science: Materials International 22(6), 693-700.

12. Gaidau C, Ignat M, Iordache O, Popescu LM, Piticescu RM, Ditu LM, Ionescu M. 2018. $\mathrm{ZnO}$ nanoparticles for antimicrobia treatment of leather surface. Revista De Chimie 69(4), 767-771.

13. Velmurugan P, Shim J, Bang KS, Oh BT. 2016. Gold nanoparticles mediated coloring of fabrics and leather for antibacterial activity. Journal of Photochemistry and Photobiology 160, 102-109.

14. Majidnia Z, Idris A, Valipour P. 2013. Evaluation of antibacteria properties of leather treated with silver nanoparticles. Jurnal Teknologi 60, 5-8.

15. John F, Sargent Jr. 2016. Nanotechnology: A policy primer. Congressional Research Service

16. Raji P, Samrot AV, Bhavya KS, Sharan M, Priya S, Paulraj P. 2019 Greener approach for leather tanning using less chrome with plant tannins and tannins mediated nanoparticles. Journal of Cluster Science 30 (6), 1533-1543.
17. Türkan MF, Aslan A, Yapici AN, Meriçli Yapici B, Bilgi ST. 2013. Assessment of antimicrobial activity of natural leathers treated with Pseudevernia furfuracea (L.) Zopf extracts. Tekstil ve Konfeksiyon 23(2), 176-180.

18. Kivrak I, Duru ME, Öztürk M, Mercan N, Harmandar M, Topçu G. 2009. Antioxidant, anticholinesterase and antimicrobial constituents from the essential oil and ethanol extract of Salvia potentillifolia. Food Chemistry 116, 470-479.

19. Wertheim HF, Melles DC, Vos MC, van Leeuwen W, van Belkum A, Verbrugh HA, Nouwen JL. 2005. The role of nasal carriage in Staphylococcus aureus infections. The Lancet Infectious Diseases 5 , 751-762.

20. Coates R, Moran J, Horsburgh MJ. 2014. Staphylococci: colonizers and pathogens of human skin. Future Microbiology 9, 75-91.

21. Tong SYC, Davis JS, Eichenberger E, Holland TL, Fowler VG Jr. 2015. Staphylococcus aureus infections: epidemiology, pathophysiology, clinical manifestations, and management. Clinical Microbiology Reviews 28(3), 603-661.

22. Dryden MS. 2010. Complicated skin and soft tissue infection. Journal of Antimicrobial Chemotherapy 65 Suppl 3, iii35-44.

23. Olszewski WL, Jamal S, Manokaran G, Pani S, Kumaraswami V Kubicka U, Lukomska B, Dworczynski A, Swoboda E, MeiselMikolajczyk F. 1997. Bacteriologic studies of skin, tissue fluid, lymph, and lymph nodes in patients with filarial lymphedema. The American Journal of Tropical Medicine and Hygiene 57(1), 7-15.

24. Lee YL, Shih SD, Weng YJ, Chen C, Liu CE. 2010. Fatal spontaneous bacterial peritonitis and necrotizing fasciitis with bacteraemia caused by Bacillus cereus in a patient with cirrhosis. Journal of Medical Microbiology 59 (Pt 2), 242-244.

25. Ikeda M, Yagihara Y, Tatsuno K, Okazaki M, Okugawa S, Moriya K. 2015. Clinical characteristics and antimicrobial susceptibility of Bacillus cereus blood stream infections. Annals of Clinical Microbiology and Antimicrobials 14(43), 1-7.

26. Domenico EGD, Cavallo I, Capitanio B, Ascenzioni F, Pimpinelli F, Morrone A, Ensoli F. 2019. Staphylococcus aureus and the Cutaneous Microbiota Biofilms in the Pathogenesis of Atopic Dermatitis. Microorganisms 7(301), 1-22.

27. Koizhaiganova M, Yas I, Gülümser G. 2015. Assessment of antibacterial activity of lining leather treated with silver doped hydroxyapatite. International Biodeterioration \& Biodegradation 105, 262-267.

28. Bayramoğlu EE, Gülümser G, Karaboz İ. The investigation of antibacterial activities od some essential oils in wet blue leather. IJNES, 2(1), 33-36 